\title{
Visitor management in protected areas
}

\author{
Josef Zelenka, Jaroslav Kacetl / e-mail: josef.zelenka@uhk.cz, jaroslav.kacetl@uhk.cz \\ Department of Recreology and Tourism, Faculty of Informatics and Management, \\ University of Hradec Králové, Czech Republic
}

Zelenka, J., \& Kacetl, J. (2013). Visitor management in protected areas. Czech Journal of Tourism, 2(1), 5-18.

doi: 10.2478/cjot-2013-0001

\begin{abstract}
Visitor management is often too narrowly connected with mass/individual tourism in protected areas. Generally, visitor management can be used in any destination for mass and individual tourism also in connection with optimization of visitor flows, visitor concentration, and optimization of visitor impacts in a very broad sense. This paper focuses on the introduction of the theoretical concept of visitor management; it discusses different visitor management approaches and their principles, compares these approaches, and shortly describes typical visitor management tools. The discussion focuses on the appropriate use of chosen selected tools, mainly carrying capacity approaches, zoning and optimization of tourism infrastructure and monitoring, including tourism sustainability indicators. The computer simulation and prediction of qualitative and quantitative characteristics of the phenomena in destination is also shortly described. The typical application of visitor management in protected areas is described as a case study and a set of recommendations for visitor management are declared.
\end{abstract}

\section{Keywords}

visitor management, carrying capacity, tourism, protected area, zoning, communication, participation

JEL classification: L83, Q01 / Accepted: 30 May 2013 


\section{Introduction}

The current interpretation of tourism (while leaving virtual and space tourism out of consideration) is the circulation of variously large and differently motivated flows of visitors into destinations on land or sea. The greatest attention in research, publications and in practice of destination management and state administration is paid to circulation and activities of participants of mass as well as individual tourism in protected areas, or more generally, in valuable areas as regards nature and landscape (specifically protected areas according to the Czech Act No. 114/1992 - national parks, protected landscape areas, national nature reserves, nature reserves, national natural monument, nature sanctuaries, and also UNESCO biosphere reserves, UNESCO geoparks and national geoparks and other areas attractive for travel and tourism with no regard to the way of their declaration and system of administration - natural parks, composed landscapes and landscape areas, culturally and historically peculiar compact areas etc.; for the detailed description of the concept see Zelenka, 2007a). Visitor flows and activities are monitored, analysed, regulated and optimized with respect to the time-space distribution, visitor activities and, if possible, the composition of visitor segments is influenced, too (see Figure 4). Optimization of visitor flows and influencing their activities and behaviour (among visitors, residents and in the area) in relation to the area may significantly increase the carrying capacity of the area (cf. Papageorgiou \& Brotherton, 1999; Zelenka, 2012; Pásková, 2012) and contribute to the local community's acceptance of visitors and their impact.

A lot of various visitor management models have been developed based on different fundaments (see Figure 6) and using to different extents various approaches. This article focuses on the analysis of essence and focus of visitor management activities, a brief analysis of its suitable methods and procedures and it compares chosen models of visitor management. Considering that the effectiveness of visitor management realisation depends on many local conditions and that scientific studies bring inspiring examples of good practice of visitor management, the chosen examples are cited as brief case studies.

\section{Definition and essence of visitor management}

According to the dictionary of tourism (Zelenka \& Pásková, 2012), visitor management is defined as a set of managerial techniques and tools used by private and public bodies of tourism (mainly by destination management organisations and in protected areas by their management) for directing visitor flows and visitor behaviour.

Visitor management is a part of destination management mainly in protected areas and destinations that systematically build sustainable tourism. Ideal model of the context of visitor management, destination management, participative management and other managerial approaches is introduced in Figure 1. It also shows that visitor management reaches maximum effectiveness if it is developed in relation with other managerial approaches. 
Figure 1 Visitor management as a part of destination management

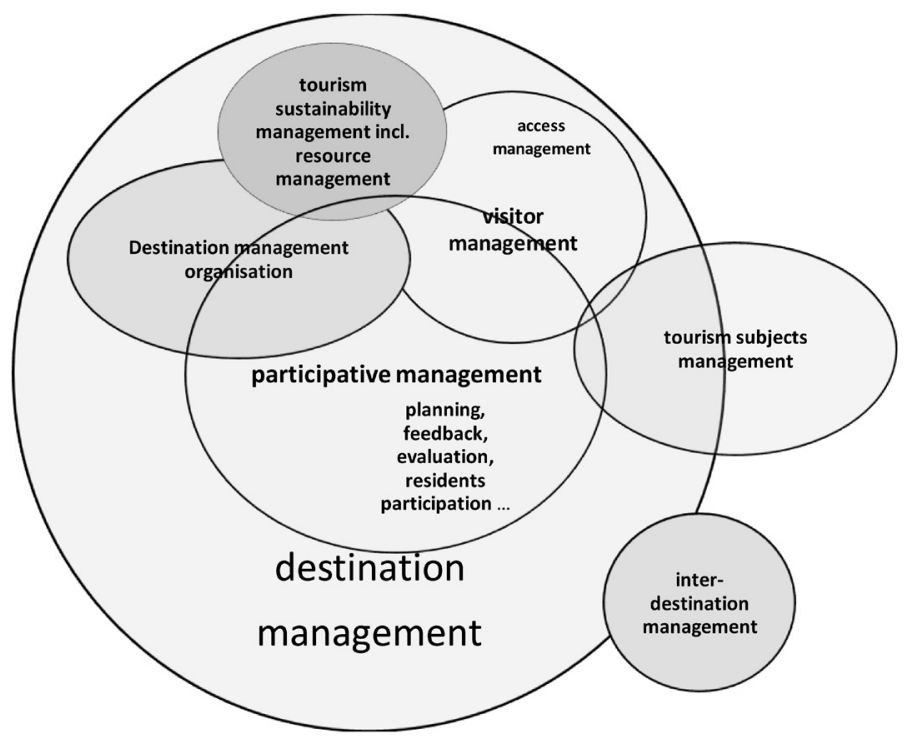

Source: Zelenka (2012a), inspired by Haugland, Nessb, Grønsethb, and Aarstad (2011)

When analysing admissions to an area, it is key to take into account the visitor's motivation, visitor distribution in time and space as well as long-term impacts of their visit (see Figure 2). Visitor motivation is based on the potential of the area for travel and tourism, on the degree and method of their activation and possibly on its degradation by travel and tourism development and by other activities in the destination. Destination potential may be related, in a simplified way, as it is stated in Figure 2, to the set of tourist attractions and their time-space distribution and the aggregate of services offered in the given destination. For a more precise evaluation of tourism development potential it is necessary to consider their activation for travel and tourism in the destination and also the factors decreasing the potential of travel and tourism (for details see for instance Bína, 2002; Vystoupil et al., 2007). Visitor motivation creates the structure of their segments for the given destination and also kind, extent and time course of visitor activities in the destination. The impact of admissions is a complex result of mainly the number of visitors and their time-space distribution, the portfolio of their activities and their will to respect the set limits of admissions. Impacts are also determined by variable particularities of the visited area (for example, various kinds of eco- and geo-systems, weather, see also the concept of carrying capacity in Zelenka, 2012) and the readiness of local community and infrastructure of travel and tourism for the influx of tourists. In relation to the carrying capacity it is suitable to distinguish long-term and short-term impacts of admissions and their reversibility or irreversibility (see Figure 2) in connection with many dimensions of carrying capacity of destination in relation to impacts on different 
components of destination environment as well as on its visitors themselves (for details see Zelenka, 2012; Pásková, 2012; Pásková, 2008; Pásková, 2003).

Figure 2 Main aspects of tourism destination visiting

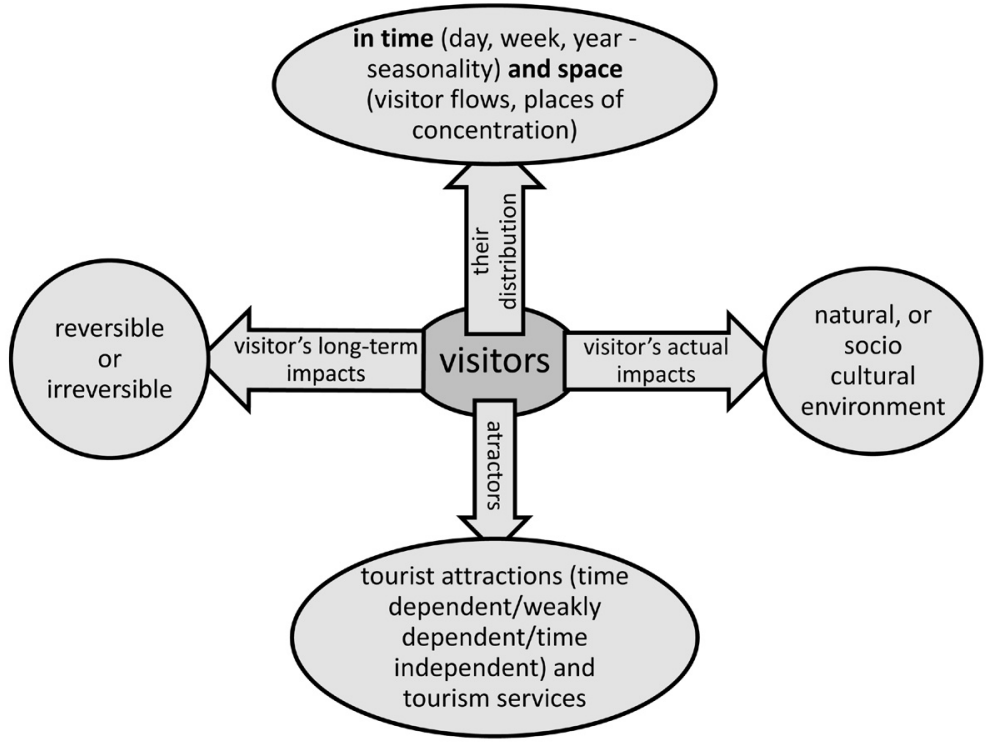

Source: authors

\section{Objectives of visitor management}

The objectives of visitor management are based on the general conception of sustainable development, which is based on looking for, defining, reaching and developing dynamic equilibrium of environmental, economic, socio-cultural, and regional aspects of the state and development of society and nature (see e.g. Zelenka, 2007b; Nováček, 2010). In the case of admissions to destination it is possible to express this process as looking for the equilibrium between the benefit from admissions and its negative impacts on visitors, residents, entrepreneurs in tourism and other participants (see Figure 3). With respect to the main phenomena connected with admissions to destination, visitor management should be in accord with the social exchange theory (e.g. Pásková, 2008; Weaver \& Lawton, 2013) aimed at maintaining and developing the visitor experiences and values achieved through the stay in the destination. It should also bring benefits for residents, entrepreneurs in tourism and for other participants (see Figure 3). At the same time, negative environmental and socio-cultural impacts on the local community and cultural and natural environment should be balanced with economic benefits and their reinvestment into reducing these negative impacts. An indispensable part of visitor management is also the regulation of admissions at overloaded locations and, on the contrary, 
promotion of off-season admissions for decreasing seasonality as well as admissions at less-known locations in order to change visitor distribution in the area and increase geographically even distribution of economic benefits. The essence of this process is to look for the equilibrium between the extent and ways of regulation and, on the other hand, support visitor activities and the extent of their free choice of activities at the destination (see Figure 3). The case study below shows a suitable approach to finding the equilibrium between the necessary regulation of activities and the offer of ways how to get to know the values of the given destination, which is readily applicable at similar destinations.

Figure 3 Balance of benefits and impacts between visitors, residents and other tourism actors

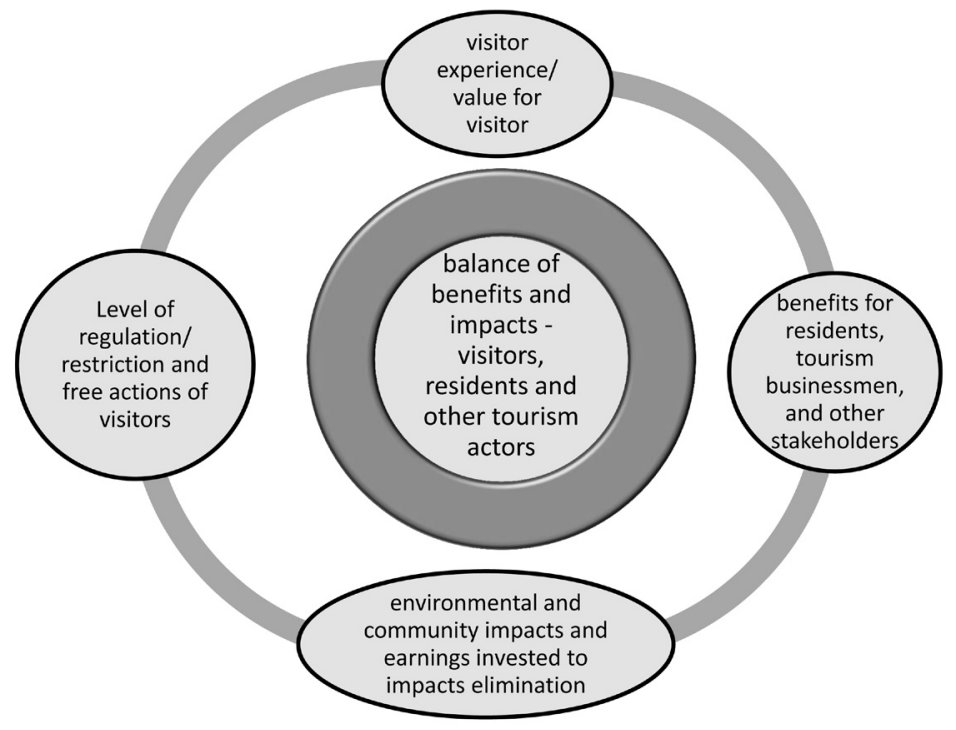

Source: authors

\section{Case study 1}

\section{Visitor management in the surroundings of Lake Greifensee, Switzerland}

This case study shows how significant it is to deal with the equilibrium between the regulation of admissions and offering ways how to get to know the values of the given destination. Bernet (2004) dealt with the effectiveness of influencing the admissions in large protected areas in the surroundings of Lake Greifensee in Switzerland. She observed that creating artificial barriers for entering protected areas with valuable ecosystems and setting out forbidding boards was inefficient and stimulated frequent vandalism. A much more effective approach was positively influencing the admissions, based on leading paths along valuable ecosystems. These paths led into the protected areas in suit- 
able places, which were divided by natural barriers (wetlands, shrubbery, etc.) and were supplemented with observation places into the area.

\section{Visitor management tools and approaches in protected areas}

According to the dictionary of tourism (Zelenka \& Pásková, 2012) and the book written by Zelenka, Těšitel, Pásková, and Kušová (2013), the following aspects are among the main tools of visitor management (adapted):

- access management with managed visitor flow in getaways to the given destination (Beunen, Regnerus, \& Jaarsma, 2008), or in other suitable places in the destination;

- optimizing paths for visitors - suitable routes in terrain, signing and maintaining of tourist trails and paths, creating nature, instructive, and experience trails;

- suitable placement and quality of interpretation infrastructure - instructive boards, visitor and information centres, tourist information centres;

- suitable methods of making the area accessible (see Case study 1), including suitable placement of getaways (Beunen, Regnerus, \& Jaarsma, 2008), car parks and related infrastructure, including visitor centres;

- in comparison with common implementation of zoning, with respect to time variability of impacts in the area, generalised time-space zoning in relation to tourism, based on respecting variably environmentally sensitive zones and species living there;

- price policy - e.g. setting different prices in various seasons in order to decrease seasonality, higher price level in the most frequently visited places in order to change spatial concentration of visitors, analysis of the visitor's willingness to pay (e.g. Chung et al, 2011);

- consistent respect to the carrying capacity for tourism (see Zelenka, 2012);

- other tools: comprehensible and clear communication with visitors, absolute regulation of their number with the need to reserve places (e.g. for canoeing - upstream of the Vltava or the Colorado rivers), implementation of codes of conduct for visitors and companies and institutions active in tourism, running educational programmes and seminars.

In relation with regulating the time-space distribution of visitors, their amounts and behaviour, the most important tools with respect to the objective of regulation are depicted in Figure 4. Individual tools cannot be viewed statically but depend on the time and topical conditions in the destination and in synergic relations of influences as it is described in the following case study (Case study 2).

\section{Case study 2}

Hippotourism in Oulanka National Park

The treatise by Siikamäki, Törn, and Tolvanen (2006) about environmental impacts of hippotourism (horseback riding) in Oulanka National Park, in the north-east Finland, 
between 2001 and 2005 was based on their own research and the comparison with previously published results. The authors concluded that even the low number of horsemen (about 80-100 per year) cause significant erosion of paths and their degradation (a similar analysis of the carrying capacity in Cole, 2004; Tolvanen et al, 2004; Monz, 2006). This erosion corresponded with similar treatises stating an essential acceleration of erosion after rain (more significant erosion of damp oil, see Pedersen, 2002) whereas the lowest erosion in woods with the lowest rainfall. The authors also described a synergic effect of treading, erosion, and introduced species. The path erosion caused by horse treading and human activities, horse excrements and humus depletion support the introduction of non-native species into the area.

Figure 4 Visitors regulation - different basic approaches

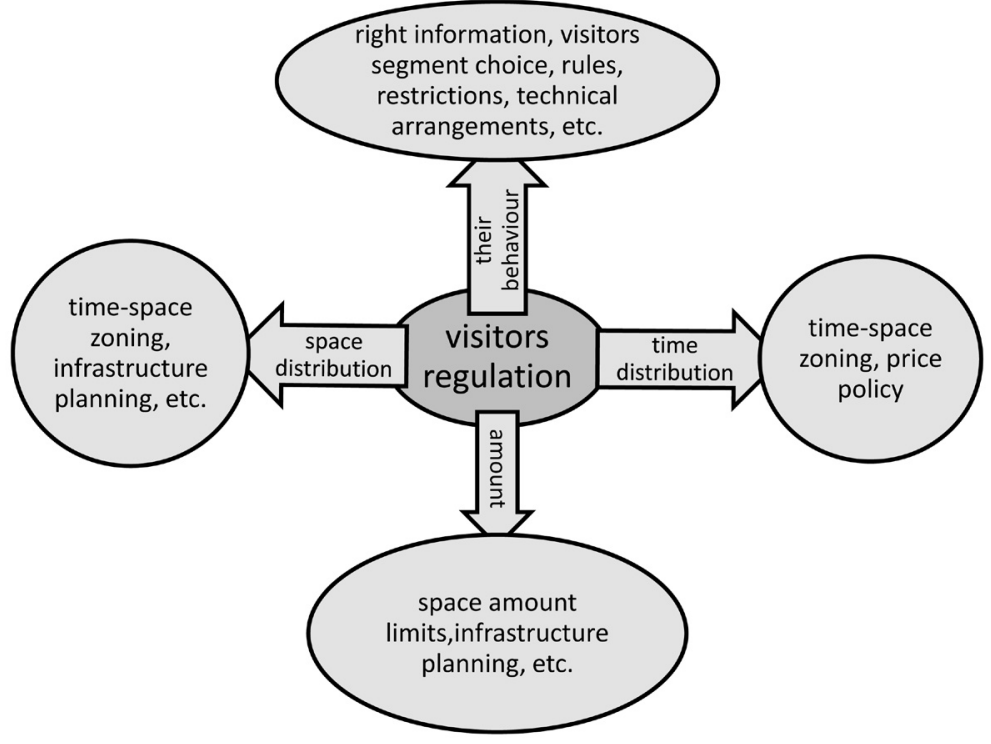

Source: authors

The role of information in visitor management is ever more significant as Figure 5 suggests with the emphasis on monitoring, communication, sharing information with other participants, information as a prerequisite for planning and prediction of development or as a supplement of outputs from monitoring with the utilisation of simulations and more generally modelling the reality.

Visitor monitoring and the impacts of visitors are the foundation of knowledge about visitors. The methodology of monitoring in protected areas is described in Eagles, McCool, and Haynes (2002), or Muhar, Arnberger, and Brandenburg (2002). Visitor monitoring ideally covers the whole area (in suitably chosen network of places in terrain), it is continual (all-year round) and made according the same methodology as in other similar areas (e.g. protected areas). Its objective is gathering data about the amounts and flows 
of visitors, about impacts of admissions in the destination and possibly about the visitors' characteristics and behaviour. The summary of monitoring methods is to be found in Muhar, Arnberger, and Brandenburg (2002) and Cessford, Cockburn, and Douglas (2002), chosen monitoring methods (paths, campsites, etc.) are described in Marion, Leung, and Nepal (2006); Rammo et al (2004); Wolf, Hagenloh, and Croft (2012).

Comprehensive, segment specific and preferably positive (see Case study 1) to restrictive ("is forbidden to ...") communication with visitors (and other participants) should be done in a number of different ways (instructive boards, visitor and interpretation centres, development of local-context services, etc.) and should focus on explaining (e.g. the necessity to regulate the entrance into certain parts of the destination), on the approach to admissions in the area, on support to sharing values of the area and cooperation, on explaining and interpreting the values of the area and on support of the experiential part of tourism.

For development of visitor management the exchange of research results from similar as well as different areas and under different circumstances (e.g. the distance of source destination from other destinations) is also important. Research enables more effective implementation of communication with visitors, determining optimal time-space zoning, linking visitor management with destination management etc. Research often brings very surprising results concerning the composition of visitors, their motivation, various influences and their time-space behavioural patterns. Two examples:

- Various authors' research shows that sometimes only a surprisingly small part of visitors to unique nature areas are motivated by a deep interest in nature - whereas e.g. Beh and Bruyere (2007) showed that all segments of visitors to three Congolese nature reserves were motivated by the wilds, Mehmetoglu (2007) came up with a different result in northern Norway in destinations with natural attractions - only $22 \%$ of visitors were motivated by these attractions;

- The treatise by Keirle and Stephens (2004), dealing with space distribution of visitors in the surroundings of Lake Llyn Ideal in Snowdonia National Park, showed the significance of trail quality for visitor flow regulation. Their observation led to a conclusion that mainly smaller groups of visitors move along the shortest links between the getaway into the area and the lake. Consequently, trails on the shortest links between getaways and attractions absorb a vast majority of visitors. Most parts of the area thus remain undisrupted by visitors.

The significance and quality of modelling phenomena connected with admissions is on the rise. Even though modelling has had a long tradition in visitor management (van Wagtendonk (2004) states that in the USA modelling of visitor flows started in 1972), it has been developing in the last few years with the rise of computer performance, the implementation of systematic monitoring (accessibility of real data), the development of GIS, artificial intelligence (e.g. utilisation of neuron networks, intelligent agents, ontology, fuzzy logics) and cognitive science (visitors' mental maps, understanding time-space behavioural patterns, more precise representation of human thinking, etc.). 
Figure 5 Information approach in visitor management

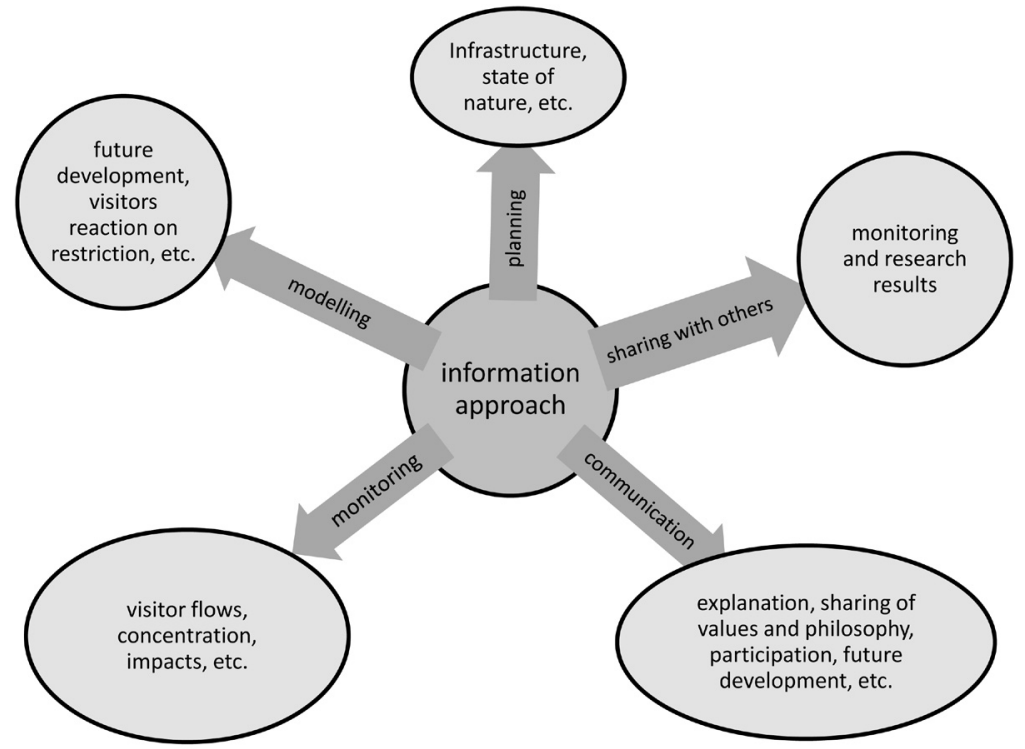

Source: authors

\section{Visitor management models}

Due to different conditions in tourism destinations (the type of destination, accessible amount of finance for destination management), a number of visitor management models have been developed. Their foundation is to retain the visitor experience (recreation opportunities spectrum - ROS, visitor experience and resource protection VERP), monitor and manage visitor impact (limits if acceptable change - LAC, visitor impact management - VIM, protected area visitor impact management - PAVIM), setting objectives and methods of their achieving (tourism optimisation model management - TOMM, visitor activity management process - VAMP) and visitor activity management (visitor monitoring and access management), see Figure 6. As follows from comparing visitor management models in Eagles, McCool, and Haynes (2002), applications of individual models are comparable in evaluating and/or minimizing visitor impact, in judging multiple cases of impacts, in choosing one out of several managerial actions, in making explicable decisions, in dividing technical information and value estimates, in supporting public involvement and shared learning and in including local resource utilisation and managerial resource problems. On the other hand, the models differ and are little or minimally effective for planning necessary investments and in total effectiveness based on experience. 
Figure 6 Visitor management approaches and their implementation in different visitor management models

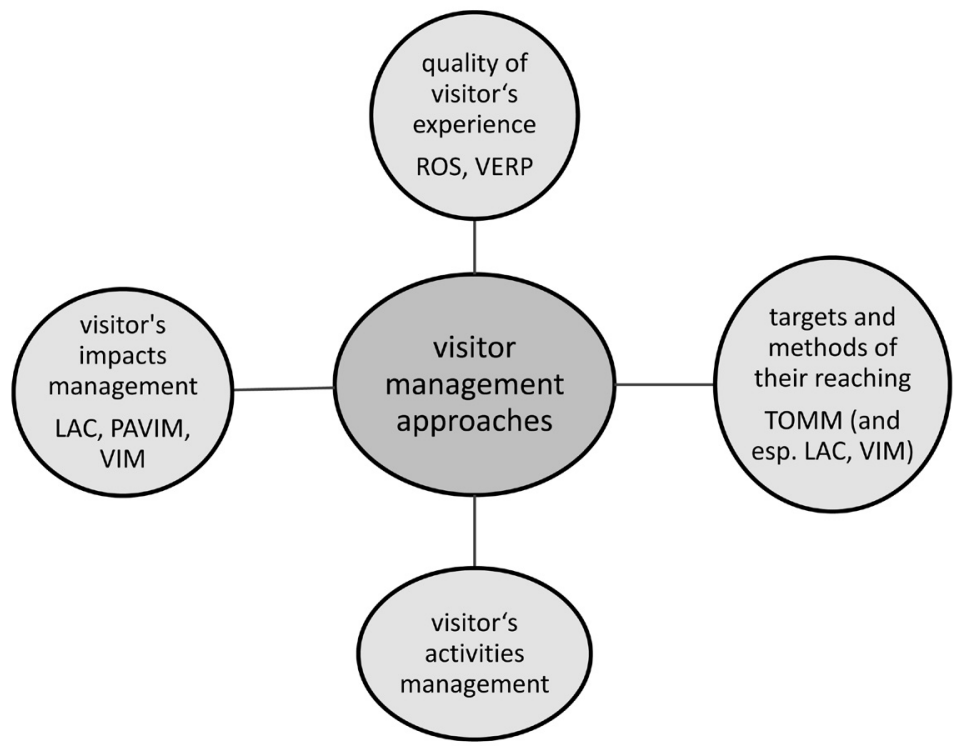

Source: authors

\section{Discussion}

The above presented destination management tools analysis and case studies could lead to a mistaken view that it is relatively easy to apply visitor management in a concrete destination: a suitable visitor management model is chosen and well-described tools of lead to achieving visitor management objectives. It is therefore important to bear in mind several significant problems.

1. Utilisation of carrying capacity concept - as it was discussed in Zelenka (2012), carrying capacity is extremely difficult to determine, due to its many dimensions, dependence on local conditions, etc. .

2. Time-space zoning in relation to tourism (utilisation of protected areas) - it is a new concept, so far insufficiently implemented and accepted in practice, difficult to communicate with tourism participants in comparison with firm geographical zoning.

3. Monitoring is so far relatively expensive and there is a lack of reliable time line from similar as well as dissimilar types of areas, which it would be possible to reliably relate to visitor flows and impacts of admissions in time.

4. Visitor flow regulation (Figure 4) is imprecisely understood only as a restriction. Nevertheless, it has a great potential in increasing the quality of visitor experiences, in improving geographical distribution of tourism benefits and in decreasing impacts 
on residents. Access regulation should be redressed with real or at least "virtual" (visitor centres, instructive boards, local guide's explication) access to valuable ecosystems or to parts of culture monuments.

5. Path and trail optimisation is understood geographically (path's and trail's route though the area, e.g. with respect to valuable ecosystems) but the quality of specific purpose trail creation, its linking to other infrastructure including customer services along the trail, their linking to viewpoints and interpretation points, objects, etc.

\section{Conclusion}

Visitor management must be a part of quality destination management not only in protected areas. It should be applied with good knowledge of conditions of the given destination, with a suitable set of tools. It should combine strategic, tactical and operational management of visitor flows, activities, behaviour, approaches and experiences. Visitor management objectives are, in compliance with sustainable development, aimed at looking for, defining, achieving and developing dynamic equilibrium between admissions benefits and its negative externalities for tourism participants. Visitor management is also based on the social exchange theory and possible negative environmental and socio-cultural impacts on the local community and cultural and natural environment are balanced with economic benefits and their reinvestment into reducing these negative impacts (see Figure 3). In case of the visitor, visitor management aims at preserving and developing the visitor experience and the value achieved by their stay at the destination (the base of some visitor management models) on the levels of interpretation, authenticity preservation, preserving and supporting the uniqueness of destination as well as optimising geographical visitor distribution at the destination (typically visitor regulation in overloaded locations and, on the contrary, promotion of admissions at less-known locations or off-season admissions). The essence of visitor management is to look for the equilibrium between the extent and ways of regulation and, on the other hand, the to support visitor activities and the extent of their free choice of activities at the destination

Visitor management has been systematically developed in recent years both on the theoretical and applied levels. Regular international conferences „International Conference on Monitoring and Management of Visitor Flows in Recreational and Protected Areas" are very important as well as the development of automated monitoring methods, including telemetric data transmission. Artificial intelligence approaches are promising, and, and may potentially forecast time-space visitor behaviour and their reaction to changes in the area. The essential visitor management tool would be further development of theoretical, mathematical and simulation tools and achieving representative sets of empirical data for implementing the carrying capacity as a substitute for current very simplified "linear approximations" (X visitors a day independently of conditions weather, season, etc.) to real, i.e. synergic, multi-parameter tourism impacts dependent on many circumstances, which define, together with the area's characteristics, the carry- 
ing capacity of the area in relation to the influences under given circumstances.

Visitor management effectiveness is based on several principles:

- Balance of strategic, tactical and operational approaches;

- Emphasis on the principle of prevention in context of impacts, retaining authenticity, admissions benefits, etc.;

- Good work with information and knowledge - historical, current as well as predictive;

- Consistent respect to local conditions;

- Utilisation of participative management approaches - cooperation with residents and other tourism participants;

- Suitable communication with tourism participants in order for them to accept managerial decisions or even actively participate in visitor management.

A suitable visitor management model may be chosen (see Figure 6), according to the type of destination and accessible amount of finance for destination management, as a frame for the implementation of visitor management. When optimising visitor management utilisation (similarly as in the case of sustainable tourism development indicators and in case of carrying capacity approaches or the LAC method), it is suitable to adjust this model to the given destination and possibly supplement it with other suitable visitor management tools. Visitor management implementation is a dynamic optimisation process, intricately linked to destination management, mainly through participative management, sustainable tourism management, resource management, destination management company and tourism subjects management (see Figure 1).

\section{Literature}

Beh, A.,\& Bruyere, B. L. (2007). Segmentation by visitor motivation in three Kenyan national reserve. Tourism Management, 28(5), 1464-1471.

Bernet, P. (2004). Interaction between nature protection and leisure groups, an example of the largest protected area surrounding Lake Greifensee, canton Zurich, Switzerland. In Proceedings of the Second International Conference on Monitoring and Management of Visitor Flows in Recreational and Protected Areas, June 16-20, Rovaniemi, Finland (pp. 136-142). Retrieved June 24, 2007, from http://www.metla.fi/julkaisut/workingpapers/2004/mwp002.htm

Beunen, R., Regnerus, H. D., \& Jaarsma, C. F. (2008). Gateways as a means of visitor management in national parks and protected areas, Tourism Management, 29(1), 138-145.

Bína, J. (2002). Hodnocení potenciálu cestovního ruchu v obcích České republiky (Evaluation of Tourism Potential in the Czech Urban areas). Urbanismus a územni rozvoj, Vol. 5, No. 1, pp. 2-11.

Cessford, G., Cockburn, S., \& Douglas, M. (2002): Developing New Visitor Counters and their Applications for Management. In A. Arnberger, C. Brandenburg, \& A. Muhar (Eds.), Proceedings International Conference on Monitoring and Management of Visitor Flows in Recreational and Protected Areas (pp. 14-20). Retrieved April 15, 2013, from http://www.boku.ac.at/ifl/veranst/ mmvconference/ 
Chung, J. Y., Kyle, G. T., Petrick, J. F., \& Absher, J. D. (2011). Fairness of prices, user fee policy and willingness to pay among visitors to a national forest. Tourism Management, 32(5), 1038-1046.

Cole, D. C. (2004). Monitoring and Management of Recreation in Protected Areas: the Contributions and Limitations of Science. Environmental Management, Vol. 2, 10-17.

Eagles, P. J. F., McCool, S. F., \& Haynes, Ch. D. (2002): Sustainable Tourism in Protected Areas: Guidelines for Planning and Management (Best Practice Protected Area Guidelines Series No. 8). UNEP/IUCN (World Commission on Protected Areas)/UN WTO. Retrieved April 1, 2013, from http://www.iucn.org/dbtw-wpd/edocs/PAG-008.pdf

Haugland, S. A., Nessb, H., Grønsethb, B. O., \& Aarstad, J. (2011). Development of tourism destinations: An Integrated Multilevel Perspective. Annals of Tourism Research, 38(1), 268-290.

Keirle, I., \& Stephens, M. (2004). Do walkers stay on footpaths? An observational study of Cwm Idwal in the Snowdonia National Park. In Proceedings of the Second International Conference on Monitoring and Management of Visitor Flows in Recreational and Protected Areas, June 16-20, Rovaniemi, Finland (pp. 143-148). Retrieved June 24, 2007, from http://www.metla.fi/julkaisut/ workingpapers/2004/mwp002.htm

Marion, J. L., Leung, Y.-F., \& Nepal, S. K. (2006). Monitoring Trail Conditions: New Methodological Considerations. The George Wright Forum, 23(2). Retrieved April 15, 2013, from http://www. georgewright.org/232marion.pdf

Mehmetoglu, M. (2007). Typologising nature-based tourists by activity - Theoretical and practical implications. Tourism Management, 28(3), 651- 660.

Monz, Ch. (2006). Recreation Ecology and Visitor Impact Research: Past, Present and Future. In D. Siegrist, et al (Eds.), Proceedings of the Third International Conference on Monitoring and Management of Visitor Flows in Recreational and Protected Areas: Exploring the Nature of Management (pp. 98-99). Rapperswil, Switzerland: University of Applied Sciences. Retrieved April 15, 2013, from http://www.wsl.ch/mmv-3/

Muhar, A., Arnberger, A., \& Brandenburg, C. (2002). Methods for Visitor Monitoring in Recreational and Protected Areas: An Overview. In A. Arnberger, C. Brandenburg, \& A. Muhar (Eds.), Proceedings International Conference on Monitoring and Management of Visitor Flows in Recreational and Protected Areas (pp. 1-6). Retrieved April 15, 2013, from http://www.boku.ac.at/ifl/veranst/ mmvconference/

Nováček, P. (2010). Udržitelný rozvoj (Sustainable Development). Olomouc, Czech Republic: Univerzita Palackého v Olomouci.

Papageorgiou, K., \& Brotherton, I. (1999). A management planning framework based on ecological, perceptual and economic carrying capacity: The case study of Vikos-Aoos National Park, Greece. Journal of Environmental Management, Vol. 56, pp. 271-284.

Pásková, M. (2003). Změny geografického prostředi vyvolané rozvojem cestovniho ruchu ve svètle kritickorealistické metodologie (Changes of Geographics Space as a Tourism Development Influence in the Light of critical realistic methodology) (Doctoral dissertation). Prague, Czech Republic: Přírodovědecká fakulta UK Praha.

Pásková, M. (2008). Udržitelnost rozvoje cestovního ruchu (Tourism Sustainability). Hradec Králové, Czech Republic: Gaudeamus Kradec Králové.

Pásková, M. (2012). Environmentalistika cestovního ruchu (Tourism Environmentalistics). Czech Journal of Tourism, 1(2), 77-113.

Pedersen, A. (2002). Managing Tourism at World Heritage Sites: a Practical Manual for World Heritage Site Managers. Paris, France: UNESCO World Heritage Centre. Retrieved May 6, 2012, from http://whc.unesco.org/en/series/1/ 
Rammo, M. et al (2004): Visitor Surveys and Visitor Impact Monitoring in Recreational Areas in State Forests of Estonia. In Proceedings of the Second International Conference on Monitoring and Management of Visitor Flows in Recreational and Protected Areas, June 16-20, Rovaniemi, Finland (pp. 397-399). Retrieved April 15, 2013, from http://www.metla.fi/julkaisut/workingpapers/2004/ mwp002.htm

Siikamäki, P., Törn, A., \& Tolvanen, A. (2006). Environmental Impacts of Recreational Horse Riding in Protected Areas. In D. Siegrist, et al (Eds.), Proceedings of the Third International Conference on Monitoring and Management of Visitor Flows in Recreational and Protected Areas: Exploring the Nature of Management (pp. 112-114). Rapperswil, Switzerland: University of Applied Sciences. Retrieved April 15, 2013, from http://www.wsl.ch/mmv-3/

Tolvanen, A. et al. (2004). Research on ecological and social sustainability of nature tourism in northern Finland. In Proceedings of the Second International Conference on Monitoring and Management of Visitor Flows in Recreational and Protected Areas, June 16-20, Rovaniemi, Finland (pp. 264-270). Retrieved April 15, 2013, from http://www.metla.fi/julkaisut/workingpapers/2004/ mwp002.htm

Van Wagtendonk, J. W. (2004). Simulation modelling of visitor flows: where have we been and where are we going?. In Proceedings of the Second International Conference on Monitoring and Management of Visitor Flows in Recreational and Protected Areas, June 16-20, Rovaniemi, Finland (pp. 127-134). Retrieved April 15, 2013, from http://www.metla.fi/julkaisut/workingpapers/2004/ mwp002.htm

Vystoupil, J. et al. (2007). Návrh nové rajonizace cestovního ruchu ČR (Proposal of the new Tourism Regionalisation). Brno, Czech Republic: Masaryk University.

Weaver D. B. \& Lawton, L. J. (2013). Resident perceptions of a contentious tourism event. Tourism Management, 37(August), 165-175.

Wolf, I. D., Hagenloh, G., \& Croft, D. B. (2012). Visitor monitoring along roads and hiking trails: How to determine usage levels in tourist sites. Tourism Management, 33(1), 16-28.

Zelenka, J. \& Pásková, M. (2012). Výkladový slovnik cestovniho ruchu (Explanatory Tourism Dictionary) (second completely re-written and expanded edition). Prague, Czech Republic: Linde.

Zelenka, J. (2007a). Metodický návod MŽP ČR upravujicí postup zajištování udržitelnosti cestovního ruchu v přrodně a krajinně cenných územich České republiky - studie (Ministry of Environment Czech Republic Methodology for Tourism Sustainability in Nature Valuable Areas). Prague, Czech Republic: Ministry of Environment.

Zelenka, J. (2007b). Ekologie a environmentalistika (Ecology and Environmentalistics). Hradec Králové, Czech Republic: Gaudeamus Hradec Králové.

Zelenka, J. (2012). Únosná kapacita v cestovním ruchu (Tourism carrying capacity). Czech Journal of Tourism, 1(2), 114-134.

Zelenka, J. (2012a). Manažerský pohled (Management view), In A. Franke, et al., Zmírňováni regionálních disparit prostřednictvím rozvoje cestovního ruchu (Relieving regional disparities by means of the development of tourism). Prague, Czech Republic: Wolters Kluwer.

Zelenka, J., Těšitel, J., Pásková, M., \& Kušová, D. (2013). Udržitelný cestovní ruch: Management cestovního ruchu v chráněných územích (Sustainable Tourism: Tourism Management in Protected Areas). Hradec Králové, Czech Republic: Gaudeamus Hradec Králové. 